\title{
Analgesic effects of physical exercise in patients with chronic musculoskeletal pain during confinement by the COVID -19 pandemic
}

\author{
Jaime Salom Moreno, Sandra Sánchez Jorge, Davinia Vicente Campos, Luis A. Berlanga \\ Facultad de Ciencias de la Salud. Universidad Francisco de Vitoria. Pozuelo de Alarcón. Madrid.
}

doi: 10.18176 /archmeddeporte.00014

Received: 03/07/2020 Accepted: 09/11/2020

Key words:

Analgesia. Central nervous system. Chronic pain. Coronavirus. Physical exercise.

\section{Summary}

Introduction: The confinement experienced during the COVID-19 pandemic in Spain for more than two months, could severely affect the condition and quality of life of patients suffering from chronic musculoskeletal pain. Taking into account the analgesic effects that physical exercise can generate, a large part of the population has carried out some kind of physical exercise at home as a mechanism for pain control, during this period.

Objective: The objective of this study was to know the type and dosage of the exercise performed, as well as the perception of the patient's pain during the confinament period.

Material and method: An ad hoc survey by a Google Form was conducted in 86 patients to find out the health status of the patients, the type of exercise they performed and the dossage of the exercise, as well as whether they had perceived a reduction in their pain during the period of confinement.

Results: The pain intensity was reduced significantly $(p=0.001)$ when some kind of exercise was done. Strength exercise exclusively was chosen by $51 \%$ of the population, and the frequencies and session time were not significantly different between the subjects who felt a reduction in pain and those who did not.

Conclusion: A schedule of physical exercise 4 days a week, for at least 50 minutes and with intensities around $77 \%$ of HRmáx of aerobic or strength training would be recommended in patients with chronic pain, as a strategy for pain reduction. The results of our study do not advise, for patients with chronic pain, combined therapy sessions, regardless of the primary location of the pain.

\section{Efectos analgésicos del ejercicio físico en pacientes con dolor crónico musculoesquelético durante el confinamiento por la pandemia COVID-19}

\section{Resumen}

Introducción: El confinamiento vivido durante la pandemia del COVID-19 en España durante más de dos meses, podría afectar severamente a la condición y calidad de vida de los pacientes que sufren dolor crónico musculoesquelético. Teniendo en cuenta los efectos analgésicos que el ejercicio físico puede generar, gran parte de la población ha realizado ejercicio físico en sus domicilios como mecanismo del control del dolor, durante este periodo.

Objetivo: El objetivo de este estudio fue conocer el tipo y la dosis de ejercicio físico realizado, así como la percepción de los pacientes en la reducción del dolor, durante el periodo de confinamiento por el COVID-19.

Material y método: Se realizó una encuesta ad hoc a través de Google Forms a 86 pacientes para conocer su estado, el tipo de ejercicio que realizaron y la cantidad de ejercicio, así como si habían percibido una reducción de su dolor durante el periodo de confinamiento.

Resultados: La intensidad de dolor disminuyó de forma significativa $(p=0,001)$ cuando se hizo algún tipo de ejercicio físico. El ejercicio de fuerza fue elegido por el 51\% de la población de forma exclusiva, y las frecuencias y el tiempo de sesión no fueron diferentes de forma significativa entre los sujetos que sintieron una reducción del dolor y los que no.

Palabras clave:

Analgesia. Sistema nervioso central.

Dolor crónico. Coronavirus.

Ejercicio físico.
Conclusión: Una programación de ejercicio físico de 4 días a la semana, durante al menos 50 minutos y con intensidades del 77\% de FCmax de ejercicio aeróbico o de fuerza sería recomendable en un paciente con dolor crónico, como estrategia para la reducción del dolor. Los resultados de nuestro estudio no aconsejan, para pacientes con dolor crónico, sesiones de terapia combinada, independientemente de la localización primaria del dolor. 


\section{Introduction}

Chronic musculoskeletal pain affects $35.7 \%$ of the European population, resulting in high socioeconomic costs ${ }^{1}$. The relationship between chronic pain and impact on the central nervous system (CNS) has been widely reported in the literature, describing the central and peripheral sensitisation mechanisms as two great pillars in the understanding of chronic pain². Although chronic musculoskeletal pain is not site-specific, patients generally have an area of pain that is either predominant, recurrent or producers greater nociception ${ }^{3,4}$. The biopsychosocial model is currently one of the treatments used to deal with chronic pain 5 .

Within this model, the performance of physical exercise is one of the key strategies to control pain. Although many studies have highlighted the clinical changes produced in the perception of musculoskeletal pain following exercise, such as isometric exercise for tendinopathies, aerobic exercise or strength programmes, the dosage of exercise and optimal frequency are not clear ${ }^{6,7}$.

It is known that the result of exercise induces the production of endogenous analgesia. However, for this to happen, certain intensities, exercise times or frequencies need to be achieved in order to stimulate the organism to produce it ${ }^{8}$. Furthermore, it should be taken into account that subjects exhibiting chronic pain are often associated with established patterns of kinesiophobia. Therefore, the first days or weeks of exercise could be key to achieving exercise adherence ${ }^{9}$. Moreover, within the basic training principles we find the neural adaptations that are generated at the start of physical exercise, which would help to create a suitable motor pattern that could improve the perception of safety and confidence with regard to the performance of physical exercise ${ }^{10}$.

During the COVID-19 pandemic, the world's population was subject to a lockdown that may have reduced the quality of life of patients suffering from chronic pain by restricting certain aspects related to their daily living activities and which helped them to control their pain. On the other hand, a large part of the population has started self-care patterns, either because it has more time available or due to a need to increase its physical activity at home. Likewise, during lockdown, many people started a physical activity that they were either not accustomed to or, for varying reasons, they did not do on a regular basis, or as a therapeutic response to try and control their pain. The endogenous analgesic mechanisms are known to show dysfunctions in subjects with chronic pain, as has been demonstrated in knee osteoarthritis processes ${ }^{11-13}$. Lannersten \& Kosek (2010) reported how patients with fibromyalgia chronic pain will exhibit alterations in the endogenous analgesic mechanisms generated by exercise ${ }^{14}$.

A number of studies have confirmed how exercise is able to reduce pain $^{15}$ and to reduce nociceptive sensitivity ${ }^{16}$ in subjects that do not exhibit chronic pain. Likewise, systematic reviews and clinical studies have confirmed that strength exercise, aquatic therapy and aerobic exercise are better strategies than inactivity in the control of chronic musculoskeletal pain ${ }^{17-19}$. There are many clinical studies in which, based on the pathology studied and the type of exercise performed, positive effects have been reported in the reduction or control of chronic pain. However, it has yet not been possible to establish the best dose of exercise to achieve this objective, given that all have been shown to be beneficial20.

\section{Study objective}

This study is directed at learning about the dosage and types of exercise performed for analgesic purposes by patients with chronic musculoskeletal pain during the COVID-19 pandemic lockdown.

\section{Material and method}

A cross-sectional, descriptive analytical study was conducted, in which the snowball sampling technique was used to recruit patients with chronic pain, with signs and symptoms during the month of April 2020.

The inclusion criteria were those described by Gatchel et al. ${ }^{21}$ and Siddall \& Cousins ${ }^{22}$ on chronic musculoskeletal pain: subjects exhibiting musculoskeletal pain that persists for more than 3 months, independently associated with the primary cause of pain persisting for more than 3 months, fear of movement, catastrophising, impairment and sensitisation of the nervous system. Additionally, the study subjects must be aged between 18-75 years, be able to read and understand Spanish, and have started to do physical activity and/or exercise during the COVID-19 pandemic lockdown, declared in Spain on $14^{\text {th }}$ March 2020. The study excluded all those who suffered from chronic pain that was not musculoskeletal in origin, those who did not record their physical activity and/or exercise, recent post-surgery patients and pregnant women.

A 21-item ad-hoc questionnaire was prepared using a form from Google Forms, of which 6 items were to describe the sample, 7 items to learn about the aspects relating to the investigation (such as the type of exercise, frequency, volume or pain) and the 8 remaining items were to compare data for the purpose of checking whether the subject met the inclusion/exclusion criteria for the study.

The questionnaire was launched electronically and the data were stored up to 26th April 2020

The ethics committee was unable to review the study, given that the authors were under lockdown and considering the exceptional measures in place at the time. As a result, the authors closely followed similar prior studies, as well as compliance with the Declaration of Helsinki. Likewise, before completing the questionnaire, the participants had to give their informed consent, which appeared on the first page thereof.

\section{Data analysis}

All the variables were analysed by descriptive statistics: continuous variables and their relationship through the t-test, and categorical variables and their relationship through the chi square test. The quantitative variables were analysed through descriptive statistics, with the calculation of central tendency, dispersion and frequency. The level of 
significance was set at $p<0.05$ for all cases. The SPSS version 22 program was used for the statistical analysis of the data obtained.

\section{Results}

129 patients were recruited, of which 43 patients were excluded as they met some of the exclusion criteria. Finally, 86 patients were included in the study, of which 43 were female and 43 male. Table 1 shows the ages and anthropometric characteristics of the study sample.

A Student t-test was performed for independent samples in order to determine whether exercise intensity reduces the perception of pain, giving statistically significant differences $(p=0.001$ ) between a reduction in the perception of pain and intensity.

The contingency tables related to the type of exercise and whether or not the perception of pain was reduced showed that those doing strength exercises had the greatest perception of a reduction in pain, with $51.1 \%$, followed by those doing aerobic exercises, with 35.6\%. When both types of exercise were combined in the same session, only $8.9 \%$ of the subjects considered that exercise reduced the pain. For other exercises, such as pilates and mobility exercises, $2.2 \%$ of participants found that this reduced the pain. With regard to the 2 participants doing the walking activity, neither found that this activity reduced the pain.

For the inter-group analysis between those subjects who perceived a reduction in pain and those who did not, an independent sample student t-test was performed in order to determine whether the frequency of exercise reduces the perception of pain. The frequency of the group that perceived a reduction in pain was $4.88 \pm 1.43$ sessions/week $(n=45)$, while the group that felt no reduction in pain was $4.89 \pm 1.64$ sessions/week ( $n=37$ ); with no significant differences between the groups ( $p=0.993$ ). The relationship between the variables for session time and reduction in pain showed that the group that perceived a reduction in pain was $53.88 \pm 26.45$ minutes/session $(n=45)$, while the group that felt no reduction in pain was $57.72 \pm 30.03$ minutes/session $(n=37$ ), with no significant differences between the groups $(p=0.540$ ). Finally, the relationship between reduction in pain and intensity of exercise showed for the group that did perceive a reduction in pain, trained at $77.66 \pm 12.64 \%$ of maximum heart rate (max $H R$ ), while the group that felt no reduction in pain trained at $50.40 \pm 15.47 \%$ of max HR, obtaining a statistically significant difference between the groups $(p=0.001)$.

With regard to the activity they performed, based on their most severe pain, it can be seen how $31.4 \%$ of participants suffer from low back pain and that they mostly selected aerobic exercises (14\%), followed by

Table 1 Demographic variables of the sample $(n=86)$.

\begin{tabular}{lc}
\hline Age & $43.87 \pm 14.45$ \\
Sex (M/F) & $43 / 43$ \\
Weight & $70.76 \pm 19.94$ \\
Height & $170.08 \pm 8.65$ \\
BMI & $24.2 \pm 2.8$ \\
\hline
\end{tabular}

$10.5 \%$ who did strength exercises, while $51.9 \%$ reported that pain was not reduced with exercise. Cervical pain was the second most predominant site, accounting for $18.6 \%$, where the subjects did resistance and aerobic exercises in the same proportion, observing how $56.2 \%$ felt that exercise did reduce pain. Patients with shoulder pain account for 14\%, with 35\% of these subjects choosing resistance exercises, with $66.7 \%$ of patients considering that their pain was reduced. Knee pain accounted for $8.1 \%$ of patients, who opted for strength exercises and the combination of aerobic and strength exercise to control the pain, with positive results for $57.1 \%$. The remaining sites account for less than $5 \%$ each, with the strategy to combine aerobic and strength exercises being the most predominant, and obtaining the highest percentages in the reduction of pain after exercise, except for those patients with pain in their hands and wrists, who saw no reduction in the sensation of pain.

\section{Discussion}

The results obtained show that the reduction in perceived pain through physical exercise could initially be dependent on intensity, having found that those patients who exercised at a greater intensity (>75\% max HR) are the ones to show a greater reduction in exerciseinduced pain.

These results are in line with other investigations, such as the one by Macefield \& Henderson (2015), who used functional magnetic resonance imaging (fMRI) to investigate the cortical and subcortical sites involved in the sensory processing of musculoskeletal pain. Their results demonstrated that muscle sympathetic nerve activity (MSNA) increases right from the start of the contraction and is dependent on the intensity of the same, determining the signalling of the central command in the $\mathrm{FMRI}^{23}$. In any case, Boulton et al. determined that MSNA is dependent on the intensity of exercise with regard to its amplitude but not with regard to its frequency, also affirming that post-exercise ischaemia does not appear to be significantly affected by this intensity ${ }^{24}$. In this regard, it is important to underscore that, although a greater intensity of exercise could be more effective in reducing pain in patients with chronic musculoskeletal pain, it could also involve a greater risk of infection by triggering an immunosuppressive response ${ }^{25}$, and could therefore be contraindicated for patients with a risk of infection and/or in situations in which the appropriate preventive measures cannot be guaranteed.

However, the analgesic effect of physical exercise is well-known. Sabharwal et al. demonstrated in mice that just 5 days of exercise could prevent the development of autonomic dysfunction and reduce the pain threshold induced by chronic musculoskeletal pain through, among other mechanisms, the induction of analgesia by central mechanisms that release endogenous opioids from the periaqueductal grey matter (PAG) and from the rostral ventromedial medulla (RVM) 25 with this latter structure being one of the possible areas related to the participation in the facilitation of the spinal nociceptive processing 
and the generation of hyperalgesia in models of inflammatory and neuropathic pain ${ }^{26}$.

In this same line, Brito et al. affirm that the practice of exercise involves a reduction in pain through the central inhibitory mechanisms involving the opioidergic and serotonergic systems in the presence of acute nociceptive effects, demonstrating that systemic naloxone, PAG naloxone and RVM naloxone reverse the anti-nociceptive effects of physical exercise in mice with induced muscle pain. Likewise, these authors also determined that exercise reduces the expression of the serotonin (SERT) receptors in these mice, which could contribute to a reduced perception of musculoskeletal pain. These studies could support the endogenous analgesia mechanisms induced by exercise, although for patients exhibiting chronic pain, these analgesic pathways could be conditioned by the central sensitisation process that accompanies pain. Therefore, dosage dependent on exercise intensity appears to be fundamental in the triggering of the endogenous mechanisms ${ }^{27}$.

The correlation results between the frequency and session time variables showed that, although not statistically significant, both variables could be related when planning physical exercise microcycles, so that there could be models in which the frequency of sessions could be increased per week without changing the total number of minutes, as discussed by Polaski et al. (2019) ${ }^{8}$. Along these same lines, the session time appears to be related to an increase in the intensity of the session, whereby exercise needs to be performed at high intensities in order to trigger the endogenous analgesic mechanisms, disregarding the proposals for exercises with a long duration at medium and/or low intensities maintained over time, as it seems that this therapeutic strategy would not trigger the opioid systems through the release of plasma $\beta$-endorphins ${ }^{28}$.

Aerobic exercises could be a suitable strategy for reducing chronic pain, given that they increase the heart rate with relative ease and make it possible to stay at parameters with high intensities with a greater control of the exercise. However, anaerobic-based exercises are a good alternative for reducing perceived pain, and this physical exercise method is the one used by many individuals in their homes through bodyweight exercises, having demonstrated that this could be sufficient to control and improve chronic pain given that the levels of $\beta$-endorphins achieved are similar to those of aerobic exercises ${ }^{29}$.

One of the limitations of our study is that the data were obtained through a self-recording process using the Google Forms platform, with no observer present to help subjects to complete the questionnaire, when in doubt.

\section{Conclusion}

A programme of aerobic or strength exercises for 4 days a week, for at least 50 minutes and with intensities of $77 \%$ max HR would be recommendable to patients suffering from chronic pain, as a pain reduction strategy. For patients with chronic pain, the results of our study do not advise combined therapy sessions, regardless of the primary site of the pain.

\section{Acknowledgements}

The authors of the study would like to thank the study participants for their time and willingness to collect the data for the study.

\section{Financing}

This study has received no funding at all.

\section{Conflict of interest}

The authors have no conflict of interest at all.

\section{Bibliography}

1. Cimas M, Ayala A, Sanz B, Agulló-Tomás MS, Escobar A, Forjaz MJ. Chronic musculoskeletal pain in European older adults: Cross-national and gender differences. Eur J Pain. 2018;22:333-45.

2. Crofford LJ.Chronic Pain: Where the Body Meets the Brain. Trans Am Clin ClimatolAssoc. 2015;126:167-83.

3. Froud R, Patterson S, Eldridge S, Seale C, Pincus T, Rajendran D, et al. A systematic review and meta-synthesis of the impact of low back pain on people's lives. BMCMusculoskelet Disord. 2014;15:50.

4. Pinheiro MB, Ferreira ML, Refshauge K, Ordoñana JR, Machado GC, Prado LR, et al. Symptoms of Depression and Risk of New Episodes of Low Back Pain: A Systematic Review and Meta-Analysis. Arthritis Care Res (Hoboken). 2015;67:1591-603.

5. Riswold K, Brech A, Peterson R, Schepper S, Wegehaupt A, Larsen-Engelkes TJ, et al. A Biopsychosocial Approach to Pain Management. SD Med. 2018;71:501-4.

6. Kroll HR. Exercise therapy for chronic pain. Phys Med Rehabil Clin NAm. 2015;26:263-81.

7. Cook JL, Rio E, Purdam CR, Docking SI. Revisiting the continuum model of tendon pathology: what is its merit in clinical practice and research? Br J Sports Med. 2016;50: 1187-91.

8. Polaski AM, Phelps AL, Kostek MC, Szucs KA, Kolber BJ. Exercise-induced hypoalgesia: A meta-analysis of exercise dosing for the treatment of chronic pain. PLoS One. 2019; 14:e0210418.

9. Vaegter HB, Madsen AB, Handberg G, Graven-Nielsen T. Kinesiophobia is associated with pain intensity but not pain sensitivity before and after exercise: an explorative analysis. Physiotherapy. 2018;104:187-93.

10. Sale DG. Neural adaptation to resistance training. Med SciSports Exerc. 1988;20:S135-45.

11. Arendt-Nielsen $L$, Nie H, Laursen MB, Laursen BS, Madeleine $P$, Simonsen $O H$, et al. Sensitization in patients with painful knee osteoarthritis. Pain. 2010;149:573-81.

12. Graven-Nielsen T, WodehouseT, Langford RM, Arendt-Nielsen L, Kidd BL. Normalization of widespread hyperesthesia and facilitated spatial summation of deep-tissue pain in knee osteoarthritis patients after knee replacement. Arthritis Rheum. 2012;64:2907-16.

13. Kosek E, Ordeberg G. Lack of pressure pain modulation by heterotopic noxious conditioning stimulation in patients with painful osteoarthritis before, but not following, surgical pain relief. Pain. 2000;88:69-78

14. Lannersten $L$, Kosek E. Dysfunction of endogenous pain inhibition during exercise with painful muscles in patients with shoulder myalgia and fibromyalgia. Pain. 2010;151:77-86.

15. Scheef L, Jankowski J, Daamen M, Weyer G, Klingenberg M, Renner J, et al. An fMRI study on the acute effects of exercise on pain processing in trained athletes. Pain. 2012;153:1702-14

16. Ellingson LD, Colbert LH, Cook DB. Physical activity is related to pain sensitivity in healthy women. Med Sci Sports Exerc. 2012;44:1401-6.

17. Bidonde J, Busch AJ, Webber SC, Schachter CL, Danyliw A, Overend TJ, Richards RS, Rader T. Aquatic exercise training for fibromyalgia. Cochrane Database Syst Rev. 2014:CD011336

18. Busch AJ, Webber SC, Richards RS, Bidonde J, Schachter CL, Schafer LA, Danyliw A, Sawant A, Bello-Haas VD, Rader T, Overend TJ. Resistance exercise training for fibromyalgia. Cochrane Database Syst Rev. 2013:CD010884. 
19. Fransen M, McConnell S, Harmer AR, Van der Esch M, Simic M, Bennell KL. Exercise for osteoarthritis of the knee. Cochrane Database Syst Rev. 2015;1:CD004376.

20. Booth J, Moseley GL, Schiltenwolf M, Cashin A, Davies M, Hübscher M. Exercise for chronic musculoskeletal pain: A biopsychosocial approach. Musculoskeletal Care. 2017;15:413-21.

21. Gatchel RJ, Peng YB, Peters ML, Fuchs PN, Turk DC. The biopsychosocial approach to chronic pain: scientific advances and future directions. Psychol Bull. 2007;133:581-624.

22. Siddall PJ, Cousins MJ. Persistent pain as a disease entity: implications for clinical management. Anesth Analg. 2004;99:510-20, table of contents.

23. Macefield VG, Henderson LA. Autonomic responses to exercise: cortical and subcortical responses during post-exercise ischaemia and muscle pain. Auton Neurosci. 2015;188:10-8.

24. Boulton D, Taylor CE, Macefield VG, Green S. Effect of contraction intensity on sympathetic nerve activity to active human skeletal muscle. Front Physiol. 2014;5:194.
25. Simpson RJ, Campbell JP, Gleeson M, Krüger K, Nieman DC, Pyne DB, et al. Can exercise affect immune function to increase susceptibility to infection? Exerc Immunol Rev. 2020;26:8-22.

26. Tillu DV, Gebhart GF, Sluka KA. Descending facilitatory pathways from the RVM initiate and maintain bilateral hyperalgesia after muscle insult. Pain. 2008:136:331-9.

27. Brito RG, Rasmussen LA, Sluka KA. Regular physical activity prevents development of chronic muscle pain through modulation of supraspinal opioid and serotonergic mechanisms. Pain Rep. 2017;2:e618.

28. Da Silva Santos R, Galdino G. Endogenous systems involved in exercise-induced analgesia. J Physiol Pharmacol. 2018;69:3-13.

29. Kraemer WJ, Dziados JE, Marchitelli LJ, Gordon SE, Harman EA, Mello R, et al. Effects of different heavy-resistance exercise protocols on plasma beta-endorphin concentrations. J Appl Physiol (1985). 1993;74:450-9. 